\title{
Reducing cycling costs in coal fired power plants through power to hydrogen
}

\author{
Luis M. Romeo ${ }^{a, *}$, Begoña Peña ${ }^{a}$, Manuel Bailera ${ }^{a}$, Pilar Lisbona $^{b}$ \\ a Escuela de Ingeniería y Arquitectura. Universidad de Zaragoza, Campus Río Ebro, María de Luna 3, 50018, \\ Zaragoza, Spain \\ ${ }^{\mathrm{b}}$ Fundación Agencia Aragonesa para La Investigación y El Desarrollo (ARAID), Zaragoza, Spain
}

\section{H I G H L I G H T S}

- Hybrid operation of PtG and fossil fuel power plant is proposed to avoid shutdowns.

- The concept allows power plant continuous operation avoiding economic losses.

- The concept provides flexibility to power plants renewable energy for $\mathrm{H} 2$ production.

- Electricity producing cost is reduced between a $20 \%$ and $50 \%$ through the use of PtG.

- The reduction of shutdown economic penalties is larger than the incomes from $\mathrm{H} 2$.

\section{A R T I C L E I N F O}

Article history:

Received 28 October 2019

Received in revised form

30 March 2020

Accepted 12 April 2020

Available online $\mathrm{xxx}$

Keywords:

Energy storage

Power-to-Gas

Fossil fuel power plants

$\mathrm{CO}_{2}$ emissions

\begin{abstract}
A B S T R A C T
The increase of renewable share in the energy generation mix makes necessary to increase the flexibility of the electricity market. Thus, fossil fuel thermal power plants have to adapt their electricity production to compensate these fluctuations. Operation at partial load means a significant loss of efficiency and important reduction of incomes from electricity sales in the fossil power plant. Among the energy storage technologies proposed to overcome these problems, Power to Gas (PtG) allows for the massive storage of surplus electricity in form of hydrogen or synthetic natural gas. In this work, the integration of a Power to Gas system ( $50 \mathrm{MWe}$ ) with fossil fuel thermal power plants $(500 \mathrm{MWe})$ is proposed to reduce the minimum complaint load and avoid shutdowns. This concept allows a continuous operation of power plants during periods with low demand, avoiding the penalty cost of shutdown. The operation of the hybrid system has been modelled to calculate efficiencies, hydrogen and electricity production as a function of the load of the fossil fuel power plant. Results show that the utilisation of PtG diminishes the specific cost of producing electricity between a $20 \%$ and $50 \%$, depending on the framework considered (hot, warm and cold start-up). The main contribution is the reduction of the shutdown penalties rather than the incomes from the sale of the hydrogen. At the light of the obtained results, the hybrid system may be implemented to increase the cost-effectiveness of existing fossil fuel power plants while adapting the energy mix to high shares of variable renewable electricity sources.
\end{abstract}

@ 2020 Hydrogen Energy Publications LLC. Published by Elsevier Ltd. All rights reserved.

\footnotetext{
* Corresponding author.

E-mail address: luismi@unizar.es (L.M. Romeo).
} 


\section{Introduction}

The massive deployment of renewable energy technologies plays an essential role to tackle climate change, leading the transition towards a decarbonised society [1]. The European Union (EU), under the Paris Agreement (2015) on Climate Change [2], has established and updated specific objectives for the Member States to comply with the binding target to globally reduce greenhouse emissions at least $40 \%$ below 1990 levels by 2030. The European Directive 2018/2001 [3] on the promotion of the use of energy from renewable resources increases the previous objective of $27 \%$ of renewable share to reach a more ambitious target of $32 \%$ by 2030 . Worldwide, the International Energy Agency (IEA) foresees a 43\% increase in the global renewable power capacity between 2017 and 2022 [4].

Important challenges related to the grid and the electric sector in general must be tackled to achieve an efficient integration of renewable technologies in the generation mix, safeguarding security and economic balance [5,6]. Most power pools are designed to favour renewable electricity to the detriment of fossil-based electricity. The former role of fossil fuel power plants (FFPP) as base-load power has almost disappeared. Nowadays FFPP operate in cycling mode with frequent start-ups/shut-downs and continuous load variations to meet demand [7]. This kind of operation does not only deteriorate the equipment [8-10] but also causes drops in energy efficiency and increment in $\mathrm{CO}_{2}$ emissions [11]. Although the additional emissions are negligible with regards to the $\mathrm{CO}_{2}$ reduction related to the savings in fossil fuel consumption ( $45 \%)$, important economic penalties are derived from the increased number of start-ups under high variable renewable energy penetration (from around 0.6 to about 1 US $\$ / M W h$ ) [12]. The cycling costs, together with the curtailment of incomes from electricity sale, could jeopardize the economic viability of fossil thermal plants.

The impacts of cycling coal power plants have been investigated during the last decade. In Europe, De Groot et al. [13] concluded that, under renewable penetration above $15 \%$, the full load hours of coal-fired power plants decreased a $53 \%$ from 2005 to 2014, while the efficiency falls up to 10 points due to part-load operation. In Germany, a potential renewable increase from $14 \%$ to $34 \%$ in the period $2013-2030$ would increase the number of start-ups and the respective costs by $81 \%$ and $119 \%$, respectively [14]. In Central Western and Eastern Europe regions, the growth in the number of start-ups and load ramps was estimated in $4-23 \%$ and $63-181 \%$, respectively [7], although the intensity of cycling operation depends strongly on the location of coal plant, being especially pronounced in Germany and the Czech Republic.

From real plant operation of two coal units of $300 \mathrm{MW}$ and $600 \mathrm{MW}$ in China, the increases in coal specific consumption and $\mathrm{CO}_{2}$ emissions were estimated in $18 \%$ and $11 \%$, respectively, at $35 \%$ load factor with respect to full load. $\mathrm{NO}_{\mathrm{x}}$ emissions also grew $10 \%$ and $108 \%$, respectively, while dust factor augmented $41 \%$ in both units. Regarding the impact of cold start-up, the $\mathrm{NO}_{\mathrm{x}}$ emissions were equivalent to the amount of 8 and $12 \mathrm{~h}$ of regular full load operation, respectively, while dust emissions are roughly equal to those emitted during $7 \mathrm{~h}$ at full load in both units [11].
Regarding economic impacts, the selling price of electricity would not cover the generation costs in FFPP, even if enough flexibility is reached to integrate renewables [15]. Hentschel et al. [16] showed that faster ramp rates does not induce significant profits, but $50 \%$ reduction in minimum complaint load (MCL) decreases start-up costs by $71.43 \%$, and increases profit by $7.11 \%$ in coal-fired power plants by avoiding the curtailment of incomes [16]. Also, lower MCL may reduce the start-up duration and subsequently its cost by $70 \%$ for hard coal plants and above $45 \%$ for lignite units $[16,17]$.

In the North-eastern China, Yin et al. analysed and compared different scenarios of wind curtailment and regulation for coal-fired power plants [18]. The optimal scenario regarding economics requires wind curtailment of about $2 \%$ (meaning 17.5 TWh) to avoid excessive variability in the FFPP. They did not consider any energy storage for managing the demand variations.

Those facilities with lower MCL take huge advantage over their competitors to avoid stops in future scenarios with high variable renewable energy penetration. In general, this minimum load in coal-fired power plants is around $30-40 \%$ of the nominal power $[15,19]$. If a particular facility is able to reduce this load (e.g., down to 30\%) when required by the grid operator, this power plant could remain working while other power plants will have to stop [20]. Moreover, the power initially assigned to those installations that finally have to stop will be distributed among the other power plants still working. Therefore, it will be highly probable that the latter will not have to operate at its MCL.

Under this framework, surplus electricity storage could be a transient solution to virtually reduce the minimum complaint load, thus favouring the cycling operation in power plants. Current share of renewables requires storage capacity ratios of $10 \%$ compared to the installed power capacity [14]. This figure could grow substantially for higher solar and wind penetration. In fact, passing from $80 \%$ to $100 \%$ renewable share in the energy mix implies to triple the capacity required for electricity storage [14]. Power to fuel will play an essential role in the future electricity market because of the versatility of fuels to be used in diverse sectors and the long-term storage character without significant losses [21-23].

Under the current transition of the energy network, this manuscript proposes the storage of electricity through Power to Gas (PtG) to reduce the minimum complaint load and avoid the shutdown of coal-fired power plants. Power to Gas consumes surplus electricity to produce hydrogen as energy vector through electrolysis (or methane through the methanation of the stored hydrogen and capture $\mathrm{CO}_{2}$ ) [24-26]. A similar concept was studied by the authors, in which surplus electricity is stored from a nuclear power plant in order to allow a coal-fired power plant to sell electricity in its place [27]. In this case, the yearly-round efficiency of the coal-fired power plant increased two points, from $33.2 \%$ to $35.2 \%$.

The objective and novelty of this paper is to demonstrate and quantify the economic benefits of reducing the minimum complaint load of coal-fired power plants through electricity storage via Power to Gas with hydrogen production. The continuous operation at MCL coupled with PtG is compared to scenarios in which shutdown takes place and conventional hot-, warm- and cold start-ups are needed. 


\section{Case study}

The coal-fired power plant selected in this work is assumed to have a gross power output of $500 \mathrm{MW}_{\mathrm{e}}$ (of which $5 \%$ are consumed by the auxiliaries) with a minimum complaint load of $40 \%$. The Power to Hydrogen system coupled to the power plant may consume up to the $10 \%$ of its nominal gross power (i.e., $50 \mathrm{MW}_{\mathrm{e}}$ ). The efficiency of the electrolyser is assumed 75\% (Alkaline type, HHV-basis), with neglecting variations at partial load [28]. The coupling of the power plant with this energy storage process provides flexibility allows virtually reducing its minimum complaint load to $30 \%$ of nominal full load (Fig. 1).

\section{Operation framework}

A reduction of the grid electricity demand or an extremely large production of renewable energy will force coal-fired power plants to reduce their operation load. If load falls below the minimum compliant load, the power plant will have to stop. The conceptual framework of the six most relevant cycling processes that describe the variation in speed and load of coal-fired power plants is given in this section (Fig. 2). These concepts and assumptions will be used while establishing the different scenarios under study which exhaustively cover the potential operation sequences of the power plants [29].

- Process 1. From 'no speed no load' (NSNL) to 'minimum complaint load' (MCL). First, the speed of the turbine increases from zero to 'full speed no load' (FSNL), which corresponds to the value at which the generator is synchronized to the grid frequency and the turbine may start generating power. Then, the load increases from FSNL to MCL. MCL is the minimum load at which the turbine is complaint with technical limitations and emissions.

The total duration of Process 1 depends on the type of startup. It will take a total of $3 \mathrm{~h}$ for hot starts (i.e., for offline periods between $6 \mathrm{~h}$ and $12 \mathrm{~h}$ prior the start), $9 \mathrm{~h}$ for warm starts (i.e., 24-48 h offline) and $21 \mathrm{~h}$ for cold starts (i.e., 72-96 h offline) [29]. It must be noted that no power output will be produced during part of Process 1; specifically, from NSNL to FSNL situations. In this study, it is assumed as simplification that the facility only produces power during the last one-third of the time, at a load equal to the MCL.

- Process 2. In this process, the load of the turbines can be varied between the minimum complaint load and the full load (FL). The ramp rate is assumed to be $2 \%$ of the full load per minute, for both increasing or reducing the load of the turbines. The time spent in Process 2 is much lower compared to the other cycling processes, and therefore neglected for the economic calculations in this study.

- Process 3. In this process, the coal-fired power plant performs a full load continuous operation.

- Process 4. In this process, the coal-fired power plant performs a continuous operation at minimum complaint load.

- Process 5. The Process 5 represents the shutdown of the power plant. The load is reduced and the speed of the turbine decreases from full load to zero, practically ceasing operation. The shutdown ramping rate is assumed to be $2 \%$ full load/min, which implies that half an hour is required to vary from full to minimum complaint load (40\%) and a total of 50 min to reach NSNL. In this study, Process 5 will be simplified as a power production equal to MCL of $1-\mathrm{h}$ duration, when computing costs and incomes.

- Process 6. This corresponds to the period in which the power plant is out of operation. It does not represent a hard-physical limit, but rather an economic limitation. Operators are interested in minimizing the number or start-ups and shut-downs to reduce thermal stress on the equipment and the subsequent O\&M costs. Also, the time spent in Process 6 must be minimized to reduce the curtailment of economic incomes.

\section{Methodology}

The three most common shut-down sequences in fossil fuel power plant have been considered (hot, warm and cold shutdown) and six reference cases have been simulated: two reference cases for hot stops ( 6 and $12 \mathrm{~h}$ ), two more cases for warm (24 and $48 \mathrm{~h}$ ) and two others for cold shut-down (86 and $110 \mathrm{~h})$. Conventional fossil fuel power plant operation is illustrated in Fig. 3 and the main difference between the reference cases is the duration of outage periods (X-axis).

The model considers the day divided in $24 \mathrm{~h}$ and calculates full and partial load performance of fossil fuel power plants according to an efficiency penalization and the state-of-theart operation behaviour. Hourly gross and net power, plant efficiency and chemical energy of the required fuel are the main technical outputs of the model. Economic parameters such as OPEX and CAPEX are calculated hourly and the fixed costs associated to the shut-downs are added. Other variables as $\mathrm{CO}_{2}$ emissions and fuel costs are also calculated.

PtG hybridation with the fossil power plant allow for avoiding the shut-down of the power plant whenever the MCL has to be reduced from $40 \%$ (200MWe/500MWe) to $30 \%$ ((20050)/500 MWe). Under hybridized operation, the fossil fuel power plant operates at $40 \%$ sending to the grid the demanded $30 \%$ and to the electrolyser the remaining $10 \%$ which corresponds to $50 \mathrm{MWe}$.

Therefore, the gross power, the efficiency and the input energy are calculated taking into account that the power plant operates at $40 \%$ load but only $30 \%$ of the power is sold to the electrical grid. The hourly economic parameters (OPEX, CAPEX and fixed cost of the stops) together with carbon emissions and fuel costs other OPEX are also calculated. Under this hybrid operation, the ramp-up of the power plant back to fullload operation (from MCL to FL) is faster since Process 1 is avoided. The hourly economic variables are also calculated for this period of time (Process 2).

\section{Efficiency penalization and emissions}

Partial load operation in coal-fired power plants worsens the radiative and convective exchanges inside the boiler, reducing thermal efficiency. Consequently, more fuel (per unit of power output) is needed and specific $\mathrm{CO}_{2}$ emissions increase. Also, the variation of the temperature reached during combustion increases specific emissions [30]. 


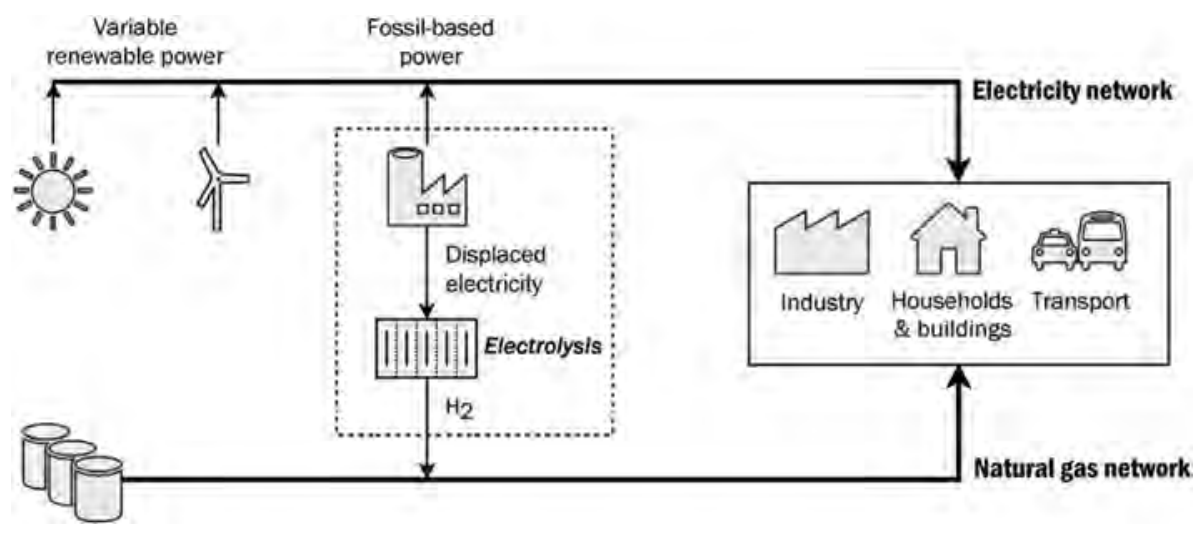

Fig. 1 - Integration of Power to Gas and fossil-based power plants in the energy system.

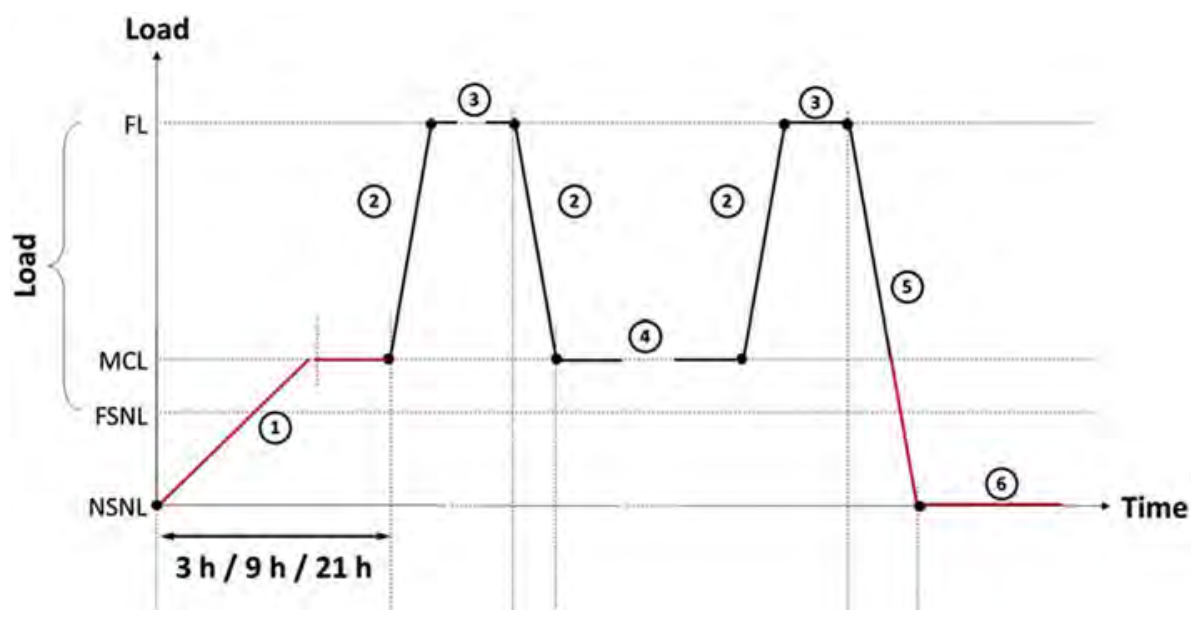

Fig. 2 - Type of cycling processes in coal-fired power plants.

Partial load curves provide the range of decrease in energy efficiency under partial load operation. According to the literature [13], a decrease of 3-8\% points could be achieved in the energy efficiency of the coal-fired power plants. Eq. (1), taken from [11] (similar to Ref. [15]), presents a linear regression model derived from an extensive set of experimental data which related gross efficiency and load operation of the plant expressed as a decimal.

$\eta_{\text {gross }}=-0.0703 \cdot$ load $^{3}+0.0507 \cdot$ load $^{2}+0.1266 \cdot$ load +0.313

Typical performance parameters of a $500 \mathrm{MW}_{\mathrm{e}}$ subcritical coal-fired power plant are calculated using Eq. (1) presented in Table 1 [11].

The specific $\mathrm{CO}_{2}$ emissions at full load amount to $785.7 \mathrm{~kg} /$ MWh (i.e., $330 \mathrm{~kg} / \mathrm{MWh}_{\mathrm{th}}$ ). The decrease in thermal efficiency makes these emissions to increase up to $898.6 \mathrm{~kg} / \mathrm{MWh}$ (an increment of $14 \%$ ) when operating at $40 \%$ load.

\section{Economics}

The economic assessment compares the cost of conventional shutdowns (hot-, warm- and cold start-ups) with the cost of continuous operation at MCL coupled with PtG. The following variables are quantified: (i) total cost (Eq. (2)), (ii) specific cost of electricity, (iii) incomes (Eq. (3)), and (iv) differential profit.
Total cost $\left[\frac{€}{h}\right]=$ OPEX $\left[\frac{€}{h}\right]+\operatorname{CAPEX}\left[\frac{€}{h}\right]$

OPEX $\left[\frac{€}{h}\right]=$ Fuel costs $\left[\frac{€}{h}\right]+$ FixedO PEX $\left[\frac{€}{h}\right]+$ Other OPEX $\left[\frac{€}{h}\right]$

Incomes $[€]=$ Net Electricity Production $[k W h]^{*}$ Electricity Price $\left[\frac{€}{k W h}\right]$

The CAPEX is assumed $2400 € / \mathrm{kW}_{\mathrm{e}}$ for the conventional coal-fired power plant [31], and $1800 €$ per $\mathrm{kW}_{\mathrm{e}}$ of installed capacity of electrolysis for the Power to Hydrogen facility [32] plus and an additional $10 \%$ due to connections to the coal power plant. This cost is distributed along the installation lifetime of 25 years. The power plant will present fixed OPEX of $35,000 € / \mathrm{MW}_{\mathrm{e}} / \mathrm{y}$ [33] and variable OPEX of $3.2 €$ per $\mathrm{MWh}_{\mathrm{e}}$ of electricity [31,34], Table 2. The total OPEX will vary between $32.3 € / \mathrm{MWh}_{\mathrm{e}}$ at full load (i.e., $25.1 € / \mathrm{MWh}_{\mathrm{e}}$ fixed plus $7.2 € /$ $\mathrm{MWh}_{\mathrm{e}}$ variable) and $41.9 € / \mathrm{MWh}_{\mathrm{e}}$ at minimum complaint load (i.e., $28.7 € / \mathrm{MWh}_{\mathrm{e}}$ fixed plus $13.2 € / \mathrm{MWh}_{\mathrm{e}}$ variable). Additional shutdown costs are included and assumed to be $75,000 €$ for hot start-up, 92,500 € for warm start-up and $140,000 €$ for cold start-up [34,35].

Other economic values presented in Table 2 are the price of coal, and the selling prices of hydrogen and electricity. It 


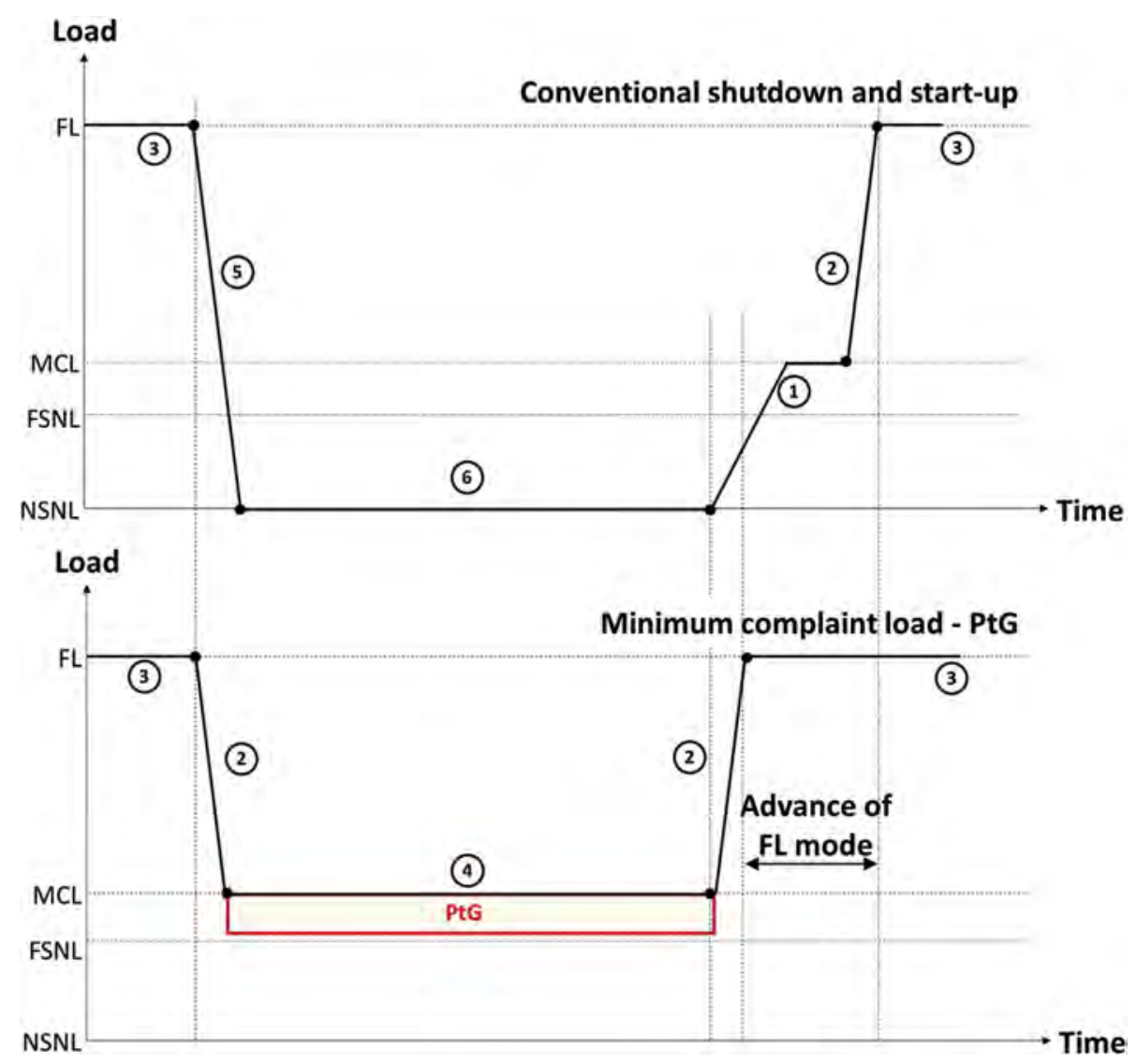

Fig. 3 - Cycling process for conventional shutdown and start-up (top), and for operation at minimum complaint load with PtG facility coupled (bottom).

has been considered a pessimistic PEM electrolyser cost by 2030 (1700 €/kWe) [36] plus an additional quantity for a hydrogen tank and an additional $10 \%$ for balance of plant (BOP). The coal fuel price considered is the average of the period 2015-2018 in the Northwest European market price according the data in [37]. It has been assumed $60 € / \mathrm{MWh}_{\mathrm{e}}$ as the lowest Electricity prices for non-household consumers [38], however this variable has high uncertainty as it is 60 pounds/MWh in the UK [39], a range between 70 and $125 € /$ MWh for several European countries [40] or up to $130 \$ / \mathrm{MWh}_{\mathrm{e}}$ in Singapore [41]. The price of hydrogen considered is based in the most cost effective hydrogen generated by steam reforming $34 € / \mathrm{MWh}[42]$. Under these assumptions, the cost of producing electricity is calculated by adding the OPEX costs (fixed cost plus coal costs) and CAPEX costs distributed in 25 years. This cost ranges from $44.3 € / \mathrm{MWh}_{\mathrm{e}}$, when operating at full load, to $53.9 € / \mathrm{MWh}_{\mathrm{e}}$ for minimum complaint load situations.

\section{Start-up scenarios}

For comparison purposes, all data related to production, emissions and economics are calculated for specific time frames: $24 \mathrm{~h}$ for the hot start-ups, $72 \mathrm{~h}$ for the warm start-ups and $120 \mathrm{~h}$ for the cold start-ups.
Table 1 - Performance of a $500 \mathrm{MW}_{\mathrm{e}}$ subcritical coal-fired power plant at partial load.

\begin{tabular}{lccc}
$\begin{array}{l}\text { Load } \\
\text { factor } \\
{[\%]}\end{array}$ & $\begin{array}{c}\text { Thermal } \\
\text { efficiency gross } \\
{[\%]}\end{array}$ & $\begin{array}{c}\text { Coal input } \\
\text { power }\left[\mathrm{MW}_{\text {th }}\right]\end{array}$ & $\begin{array}{c}\text { Specific } \mathrm{CO}_{2} \\
\text { emissions } \\
{\left[\mathrm{kgCO}_{2} / \mathrm{MWh}\right]}\end{array}$ \\
\hline 100 & 42.00 & 1190.5 & 785.7 \\
90 & 41.68 & 1079.8 & 791.8 \\
80 & 41.07 & 973.9 & 803.4 \\
70 & 40.24 & 869.9 & 820.2 \\
60 & 39.20 & 765.3 & 841.8 \\
50 & 38.02 & 657.6 & 868.0 \\
40 & 36.73 & 544.6 & 898.6 \\
\hline
\end{tabular}

Scenario 1 - Hot start-up

Fig. 3 illustrates the two different operating modes compared in Scenario 1. These two modes correspond to (i) conventional and (ii) PtG concept operation when the load of the power plant required by the grid operator is below MCL. In conventional shutdowns the power plant follows the sequence 5, 6, 1 and 2 of the processes described in Section Case study, while in the proposed concept using Power to Gas follows the sequence 2, 4 and 2 of these processes. As Scenario 1 considers hot start-up, the duration of Process 1 (i.e., from NSNL to MCL) will be $3 \mathrm{~h}$, during which power is produced only for $1 \mathrm{~h}$ and at a load equal to MCL (see section Case study). 
The results section presents the analysis of single shutdowns of 6 and $12 \mathrm{~h}$ duration, within a time framework of $24 \mathrm{~h}$.

\section{Scenario 2 - Warm start-up}

Under longer shutdown periods, the situation described in Fig. 3 is a very conservative assumption, since the grid operator will probably require a load increment during the shutdown. This requirement is associated to the instantaneous coverage of the load coming from other less flexible power plants that are forced to stop. Hence, besides the situations described in Fig. 3, an additional case is studied in Scenario 2. This additional case considers a temporary load increase from MCL to full load during the shutdown period (Fig. 4). It is only considered for the operation with PtG, as conventional operation would present a very limited time at full load due to the time spent in Process 1 (illustrated in the bottom graph of Fig. 4).

The analysis of the Scenario 2 is performed in a time frame of $72 \mathrm{~h}$. For each of the three cases (i.e., conventional, PtG, and PtG with temporary full load), two single shutdowns of 24 and $48 \mathrm{~h}$ are studied. The duration of the temporary load increment is fixed at $12 \mathrm{~h}$ in both cases (PtG keeps working until $100 \%$ load is reached). Also, as Scenario 2 considers warm start-up, the duration of Process 1 will be $9 \mathrm{~h}$, during which power is produced only for $3 \mathrm{~h}$ at MCL.

\section{Scenario 3 - Cold start-up}

Scenario 3 analyses the same cases that Scenario 2, assuming a longer time frame and a cold start-up. Hence, it is compared the conventional shutdown (Fig. 3, top), the continuous operation at MCL thanks to Power to Gas (Fig. 3, bottom), and the operation at MCL through PtG with a temporary load increment up to full load (Fig. 4, middle).

The analysis is performed in a time frame of $120 \mathrm{~h}$. For each of the three cases, two single shutdowns of 72 and $96 \mathrm{~h}$ are studied. The duration of the temporary load increment is fixed at $24 \mathrm{~h}$. Also, as cold start-up is assessed, the duration of

Table 2 - Main assumptions of the model.

\begin{tabular}{|c|c|c|}
\hline Variable & Value & Reference \\
\hline \multicolumn{3}{|l|}{ Technical } \\
\hline Gross power plant output $\left[\mathrm{MW}_{\mathrm{e}}\right]$ & 500 & \\
\hline Ancillaries' consumption [\%] & 5 & \\
\hline Net power plant output $\left[\mathrm{MW}_{\mathrm{e}}\right]$ & 475 & \\
\hline Power to Hydrogen capacity $\left[\mathrm{MW}_{\mathrm{e}}\right]$ & 50 & \\
\hline Electrolyser efficiency [\%] & 75 & [28] \\
\hline \multicolumn{3}{|l|}{ Economic } \\
\hline CAPEX power plant $\left[€ / \mathrm{kW}_{\mathrm{e}}\right]$ & 2400 & [31] \\
\hline CAPEX Power to Hydrogen $\left[€ / \mathrm{kW}_{\mathrm{e}}\right]$ & $1800+10 \%$ & [36] \\
\hline Fixed OPEX $\left[€ / \mathrm{MW}_{\mathrm{e}} / \mathrm{y}\right]$ & 35,000 & [33] \\
\hline Variable OPEX [€/MWh $\left.\mathrm{Mh}_{\mathrm{th}}\right]$ & 3.2 & {$[31,34]$} \\
\hline \multicolumn{3}{|l|}{ Shutdown cost $[€]$} \\
\hline Hot start-up & 75,000 & {$[34,35]$} \\
\hline Warm start-up & 92,500 & {$[34,35]$} \\
\hline Cold start-up & 140,000 & {$[34,35]$} \\
\hline Coal fuel price $\left[€ / \mathrm{MWh}_{\mathrm{th}}\right]$ & 10 & [37] \\
\hline Pool electricity price $\left[€ / \mathrm{MWh}_{\mathrm{e}}\right]$ & 60 & [38] \\
\hline Hydrogen price $\left[€ / \mathrm{MWh}_{\mathrm{th}}\right]$ & 30 & [42] \\
\hline
\end{tabular}

Process 1 will be $21 \mathrm{~h}$, during which power is produced only for $7 \mathrm{~h}$ at MCL.

\section{Results}

\section{Scenario $1-$ Hot start-up}

In this section, the conventional shutdown is compared with the continuous operation at MCL through Power to Gas. The technical and economic results are gathered in Table 3 for shutdowns of 6 and $12 \mathrm{~h}$ duration in a time frame of $24 \mathrm{~h}$.

It can be seen that despite the duration of the shutdown is limited, conventional operation leads to economic losses in both cases. For $6 \mathrm{~h}$ shutdowns, the costs associated to the start-up process makes profits to be negative. While for $12 \mathrm{~h}$ shutdowns, the curtailment of incomes from selling the electricity is equally critical. Considering the $24 \mathrm{~h}$ time frame, the specific cost of produced electricity increases up to $67.0 € /$ $\mathrm{MWh}_{\mathrm{e}}$ and $93.6 € / \mathrm{MWh}_{\mathrm{e}}$.

When the plant is continuously operated at minimum complaint load, the sale of electricity increases $30 \%-72 \%$ (6 h-12 h shutdowns respectively) and start-up costs are avoided. Thus, specific production costs are kept in the range 52-61 $€ / \mathrm{MWh}_{\mathrm{e}}$, which is below or close above the selling price. This decrease of production costs transforms the conventional shutdown situation with economic losses into a profitable operation.

In order to make comparisons, the differential profit is preferred. This economic parameter is the difference between the profits of the two alternative proposals, i.e., the potential savings. Thus, the continuous operation at MCL through PtG allows saving $124,740-145,375 €$ when the shutdown lasts for $6-12 \mathrm{~h}$.

As expected, the application of Power to Gas provides higher savings at longer shutdown periods. Nevertheless, most part of the incomes comes from the electricity sale. The potential incomes related to hydrogen sale represent only between $5.4 \%$ and $9.3 \%$ of the differential profit. Therefore, the economic improvement of the alternative mode of operation (continuous MCL via PtG) is not related to the energy storage technology that is used but to the avoidance of the shutdown itself.

It should be mentioned that avoiding shutdowns makes $\mathrm{CO}_{2}$ emissions to grow $36 \%$ and $92 \%$ (for $6 \mathrm{~h}$ and $12 \mathrm{~h}$ shutdowns, respectively) as the coal consumption increases in the same proportion.

\section{Scenario 2 - Warm start-up}

In Scenario 2, medium outages periods (24-48 h) are assessed under a reference time frame of $72 \mathrm{~h}$, Table 4 . The conventional shutdown with warm start-up is compared to the continuous operation at MCL, and to the operation at MCL with a temporary power production at full load.

As in Scenario 1, the absolute profit of conventional shutdowns is negative. It may be noticed that in this case there is a remarkable difference in profit values when comparing the $24 \mathrm{~h}$ and $48 \mathrm{~h}$ shutdowns, Fig. 5. This divergence is mainly associated to the ratio between the offline period and the time 


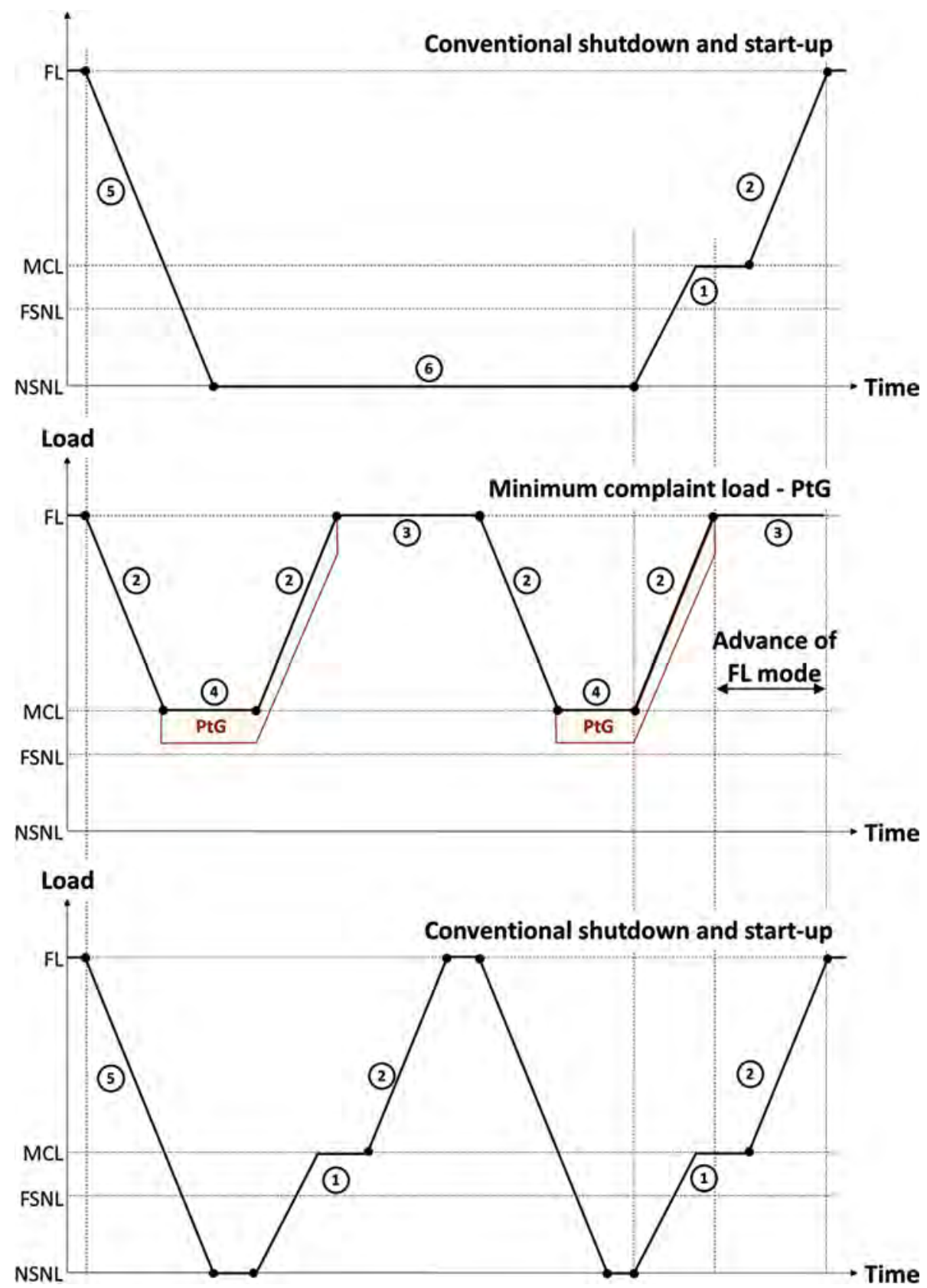

Fig. 4 - Cycling process for conventional shutdown and start-up (top), for operation at minimum complaint load with PtG and intermediate full load period (middle), and for conventional shutdown and start-up with intermediate full load period (bottom).

frame. In the $48 \mathrm{~h}$ shutdown, the offline period consumes twothirds of the reference time frame, while the warm start-up spends 9 additional hours. This gives a total of $57 \mathrm{~h}$, representing the $80 \%$ of the total time frame of $72 \mathrm{~h}$. Thus, the electricity production is very limited and the economic results are conditioned by this fact. In any case, as conclusions are drawn by the differential profit between the Power to Gas concept and the conventional operation, the influence of the time frame is palliated.

Regarding the specific cost of generating electricity, it increases up to $64.3 € / \mathrm{MWh}_{\mathrm{e}}$ and $119.9 € / \mathrm{MWh}_{\mathrm{e}}$ for conventional shutdowns of 24 and $48 \mathrm{~h}$, respectively. When the outage is avoided by continuously operating at MCL via $\mathrm{PtG}$, the specific cost diminishes to $54.2 € / \mathrm{MWh}_{\mathrm{e}}$ and $68.7 € /$ $\mathrm{MWh}_{\mathrm{e}}$. Under this concept, the former value becomes competitive, presenting costs below the selling price. Additionally, both values are lowered to $49.9 € / \mathrm{MWh}_{\mathrm{e}}$ and $60.1 € /$ $\mathrm{MWh}_{\mathrm{e}}$ in the case that the grid operator requires temporarily to rise load to $100 \%$ (12 h) during the offline period.

The revenues from the sale of hydrogen may represent a higher percentage of the differential profit than in Scenario 1, but still the avoidance of the shutdown is the main 
Table 3 - Conventional shutdown operation vs. continuous operation at MCL (PtG) under Scenario 1 assumptions. Bold represents the key variables of the system.

\begin{tabular}{|c|c|c|c|c|}
\hline Case & $\begin{array}{l}\text { Conventional } \\
\text { shutdown }\end{array}$ & $\begin{array}{l}\text { MCL with } \\
\text { PtG }\end{array}$ & $\begin{array}{l}\text { Conventional } \\
\text { shutdown }\end{array}$ & $\begin{array}{l}\text { MCL with } \\
\text { PtG }\end{array}$ \\
\hline Start-up & Hot & $\mathrm{n} / \mathrm{a}$ & Hot & $\mathrm{n} / \mathrm{a}$ \\
\hline Shutdown duration [h] & 6 & 6 & 12 & 12 \\
\hline Time frame $[\mathrm{h}]$ & 24 & 24 & 24 & 24 \\
\hline \multicolumn{5}{|l|}{ Technical data } \\
\hline Input coal [MWh $\mathrm{Hh}_{\mathrm{th}}$ & $17,645.34$ & $24,075.83$ & $10,502.48$ & $20,200.48$ \\
\hline Electricity produced (total) [MWhe] & 6982.50 & 9105.00 & 4132.50 & 7095.00 \\
\hline $\begin{array}{l}\text { Electricity production increment with respect to conventional } \\
\text { shutdown }\left[\mathrm{MWh}_{\mathrm{e}}\right]\end{array}$ & $\mathrm{n} / \mathrm{a}$ & 2122.50 & $\mathrm{n} / \mathrm{a}$ & 2962.50 \\
\hline Electricity directed to PtG $\left[\mathrm{MWh}_{\mathrm{e}}\right]$ & $\mathrm{n} / \mathrm{a}$ & 300.00 & $\mathrm{n} / \mathrm{a}$ & 600.00 \\
\hline Stored energy $\left(\mathrm{H}_{2}\right)$ [MWh] & $\mathrm{n} / \mathrm{a}$ & 225.00 & $\mathrm{n} / \mathrm{a}$ & 450.00 \\
\hline $\mathrm{CO}_{2}$ emissions $[\mathrm{t}]$ & 5823 & 7945 & 3466 & 6666 \\
\hline \multicolumn{5}{|l|}{ Economic data } \\
\hline Costs $[€]$ & 392,736 & 476,975 & 311,708 & 432,642 \\
\hline Start-up cost $[€]$ & 75,000 & $\mathrm{n} / \mathrm{a}$ & 75,000 & $\mathrm{n} / \mathrm{a}$ \\
\hline Total costs $[€]$ & 467,736 & 476,975 & 386,708 & 432,642 \\
\hline Cost increment with respect to conventional shutdown [€] & $\mathrm{n} / \mathrm{a}$ & 9239 & $\mathrm{n} / \mathrm{a}$ & 45,934 \\
\hline Incomes electricity [€] & 418,950 & 546,300 & 247,950 & 425,700 \\
\hline Incomes $\mathrm{H}_{2}[€]$ & $\mathrm{n} / \mathrm{a}$ & 6750 & $\mathrm{n} / \mathrm{a}$ & 13,500 \\
\hline Total Incomes $[€]$ & 418,950 & 553,050 & 247,950 & 439,200 \\
\hline Profit [€] & $-48,786$ & $-138,758$ & 76,075 & 6738 \\
\hline Differential profit $[€ / 24 \mathrm{~h}]$ & $\mathrm{n} / \mathrm{a}$ & 124,861 & $\mathrm{n} / \mathrm{a}$ & 145,496 \\
\hline Differential hourly profit [€/h] & $\mathrm{n} / \mathrm{a}$ & 5203 & $\mathrm{n} / \mathrm{a}$ & 6062 \\
\hline Specific cost of electricity [€/MWh $\left.\mathrm{M}_{\mathrm{e}}\right]$ & 66.99 & 52.39 & 93.58 & 60.95 \\
\hline Specific cost of additional electricity [€/MWh] & $\mathrm{n} / \mathrm{a}$ & 4.35 & $\mathrm{n} / \mathrm{a}$ & 15.44 \\
\hline
\end{tabular}

contribution. The income from hydrogen ranges between $10.4 \%$ and $15.8 \%$ of the differential profit when operating continuously at MCL, and it decreases to $3.4 \%-8.4 \%$ if a temporary load increment is demanded.

The hourly differential profits are lower than for hot startups in Scenario 1 if continuous operation at MCL is performed (from $3600 € / \mathrm{h}$ to $4750 € / \mathrm{h}$ ), but higher if the temporary load increase is required ( $5525 € / \mathrm{h}$ to $6670 € / \mathrm{h}$ ). This clearly shows that the lower contribution of $\mathrm{H}_{2}$ incomes to the differential profit, the higher the hourly differential profit.

\section{Scenario 3 - Cold start-up}

In Scenario 3, long outages of 72 and $96 \mathrm{~h}$ are considered, within a total time frame of $120 \mathrm{~h}$. Besides, the operation under conventional shutdown uses cold start-up to resume power production, spending 21 additional hours in this process. Thus, according to the assumptions in Section Case study, the longer shutdown in conventional operation will present $110 \mathrm{~h}$ without power production, $7 \mathrm{~h}$ at MCL, and $3 \mathrm{~h}$ at full load. This limited electricity production leads to a specific cost of $950 € / \mathrm{MWh}_{\mathrm{e}}$ in the time frame of $120 \mathrm{~h}$. In Scenario 3, the specific cost of electricity is below the selling price (i.e., below $60 € / M W h_{\mathrm{e}}$ ) only in the case of $72 \mathrm{~h}$ shutdown, operating at MCL through PtG, and attending the operator's requirement of a load increment to $100 \%$ for $24 \mathrm{~h}$ (Table 5, third column). Hence, positive economic profit is only found under this particular case. Nevertheless, the differential profit is remarkable in all cases, and may be as high as $588,800 €$ for the best case.
As in the previous scenarios, when the profit generated from the hydrogen sale is relevant (e.g., up to $46.3 \%$ of the differential profit in the case of $72 \mathrm{~h}$ shutdown), the differential hourly profit decreases (down to $1457 € / \mathrm{h}$ in this case).

\section{Sensitivity analysis}

The most significant and uncertain economic parameters used in the calculations of the model are the CAPEX cost of the PtG system and the costs of shut-down and start-ups. A sensitivity analysis was performed to determine the effect of the assumed parameters in the obtained results. CAPEX cost of the PtG system is varied a $20 \%$, while coal and shut-down and start-up costs are varied a $10 \%$.

Table 6 summarizes the economic results for the Scenario 1 (Hot start-up with stops of 6 and $12 \mathrm{~h}$ ) and Scenario 3 (Cold start-up with $72 \mathrm{~h}$ stop). As previously analysed, the base case shows losses in the reference case, i.e. current power plants, and profits when PtG is used to virtually reduce MLC and to store energy. In the case of a hot stops of $6 \mathrm{~h}$, the difference between both cases totalized $124,861 €(76,075-(-48,786))$. The influence of a $20 \%$ change in PtG CAPEX is not relevant with a variation of $3 \%$ in the profit of the PtG cases. The influence in the coal cost is the most relevant variable in this sensitivity analysis. In this case, a variation of $10 \%$ in the coal cost changes the economic results of reference and PtG cases. The net profit in the case of an increment of $10 \%$ adds up $118,430 €$ similar to the base case but with different addends $(51,999-(-66,431))$. If coal cost decreases the profit is $131,292 €$. Finally, a $10 \%$ variation of the shut-down and start- 
Table 4 - Conventional shutdown operation vs. continuous operation at MCL (PtG) vs. continuous operation at MCL (PtG) with temporary Full Load, under Scenario 2 assumptions. Bold represents the key variables of the system.

Case

Conventional MCL MCL with PtG and Conventional MCL MCL with PtG and shutdown with PtG temporary FL shutdown with PtG temporary FL

\begin{tabular}{lllllll}
\hline Start-up & Warm & $\mathrm{n} / \mathrm{a}$ & $\mathrm{n} / \mathrm{a}$ & Warm & $\mathrm{n} / \mathrm{a}$ & $\mathrm{n} / \mathrm{a}$ \\
Shutdown duration $[\mathrm{h}]$ & 24 & 24 & 24 & 48 & 48 & 48 \\
Temporary Full Load duration $[\mathrm{h}]$ & $\mathrm{n} / \mathrm{a}$ & $\mathrm{n} / \mathrm{a}$ & 12 & $\mathrm{n} / \mathrm{a}$ & $\mathrm{n} / \mathrm{a}$ & 12 \\
Time frame $[\mathrm{h}]$ & 72 & 72 & 72 & 72 & 72 & 72
\end{tabular}

\begin{tabular}{|c|c|c|c|c|c|c|}
\hline \multicolumn{7}{|l|}{ Technical data } \\
\hline Input coal $\left[\mathrm{MWh}_{\mathrm{th}}\right]$ & $47,305.93$ & $69,592.63$ & $77,368.98$ & $18,734.50$ & $54,091.22$ & $61,867.57$ \\
\hline Electricity produced (total) $\left[\mathrm{MWh}_{\mathrm{e}}\right]$ & $18,762.50$ & $25,875.00$ & $29,895.00$ & 7362.50 & $17,835.00$ & $21,855.00$ \\
\hline $\begin{array}{l}\text { Electricity production increment with } \\
\text { respect to conventional shutdown }\left[\mathrm{MWh}_{\mathrm{e}}\right]\end{array}$ & $\mathrm{n} / \mathrm{a}$ & 7112.50 & $11,132.50$ & $\mathrm{n} / \mathrm{a}$ & $10,472.50$ & $14,492.50$ \\
\hline Electricity directed to PtG $\left[\mathrm{MWh}_{\mathrm{e}}\right]$ & $\mathrm{n} / \mathrm{a}$ & 1200 & 600 & $\mathrm{n} / \mathrm{a}$ & 2400 & 1800 \\
\hline Stored energy $\left(\mathrm{H}_{2}\right)[\mathrm{MWh}]$ & $\mathrm{n} / \mathrm{a}$ & 900 & 450 & $\mathrm{n} / \mathrm{a}$ & 1800 & 1350 \\
\hline $\mathrm{CO}_{2}$ emissions [t] & 15,611 & 22,966 & 25,532 & 6182 & 17,850 & 20,416 \\
\hline \multicolumn{7}{|l|}{ Economic data } \\
\hline Costs $[€]$ & $1,114,228$ & $1,400,737$ & $1,490,021$ & 790,113 & $1,222,683$ & $1,311,967$ \\
\hline Start-up cost $[€]$ & 92,500 & $\mathrm{n} / \mathrm{a}$ & $\mathrm{n} / \mathrm{a}$ & 92,500 & $\mathrm{n} / \mathrm{a}$ & $\mathrm{n} / \mathrm{a}$ \\
\hline Total costs $[€]$ & $1,206,728$ & $1,400,737$ & $1,490,021$ & 882,613 & $1,222,683$ & $1,311,967$ \\
\hline $\begin{array}{l}\text { Cost increment with respect to conventional } \\
\text { shutdown }[€]\end{array}$ & $\mathrm{n} / \mathrm{a}$ & 194,009 & 283,293 & $\mathrm{n} / \mathrm{a}$ & 340,070 & 429,354 \\
\hline Incomes electricity [€] & $1,125,750$ & $1,552,500$ & $1,793,700$ & 441,750 & $1,070,100$ & $1,311,300$ \\
\hline Incomes $\mathrm{H}_{2}[€]$ & $\mathrm{n} / \mathrm{a}$ & 27,000 & 13,500 & $\mathrm{n} / \mathrm{a}$ & 54,000 & 40,500 \\
\hline Total Incomes $[€]$ & $1,125,750$ & $1,579,500$ & $1,807,200$ & 441,750 & $1,124,100$ & $1,351,800$ \\
\hline Profit $[€]$ & $-80,978$ & 178,763 & 317,179 & $-440,863$ & $-98,583$ & 39,833 \\
\hline Differential profit [€/24h] & $\mathrm{n} / \mathrm{a}$ & 259,740 & 398,157 & $\mathrm{n} / \mathrm{a}$ & 342,280 & 480,697 \\
\hline Differential hourly profit $[€ / \mathrm{h}]$ & $\mathrm{n} / \mathrm{a}$ & 3602 & 5530 & $\mathrm{n} / \mathrm{a}$ & 4754 & 6676 \\
\hline Specific cost of electricity $\left[€ / \mathrm{MWh}_{\mathrm{e}}\right]$ & 64.32 & 54.13 & 49.84 & 119.88 & 68.56 & 60.03 \\
\hline $\begin{array}{l}\text { Specific cost of additional electricity } \\
{[€ / \mathrm{MWh}]}\end{array}$ & $\mathrm{n} / \mathrm{a}$ & 27.28 & 25.45 & $\mathrm{n} / \mathrm{a}$ & 32.47 & 29.63 \\
\hline
\end{tabular}

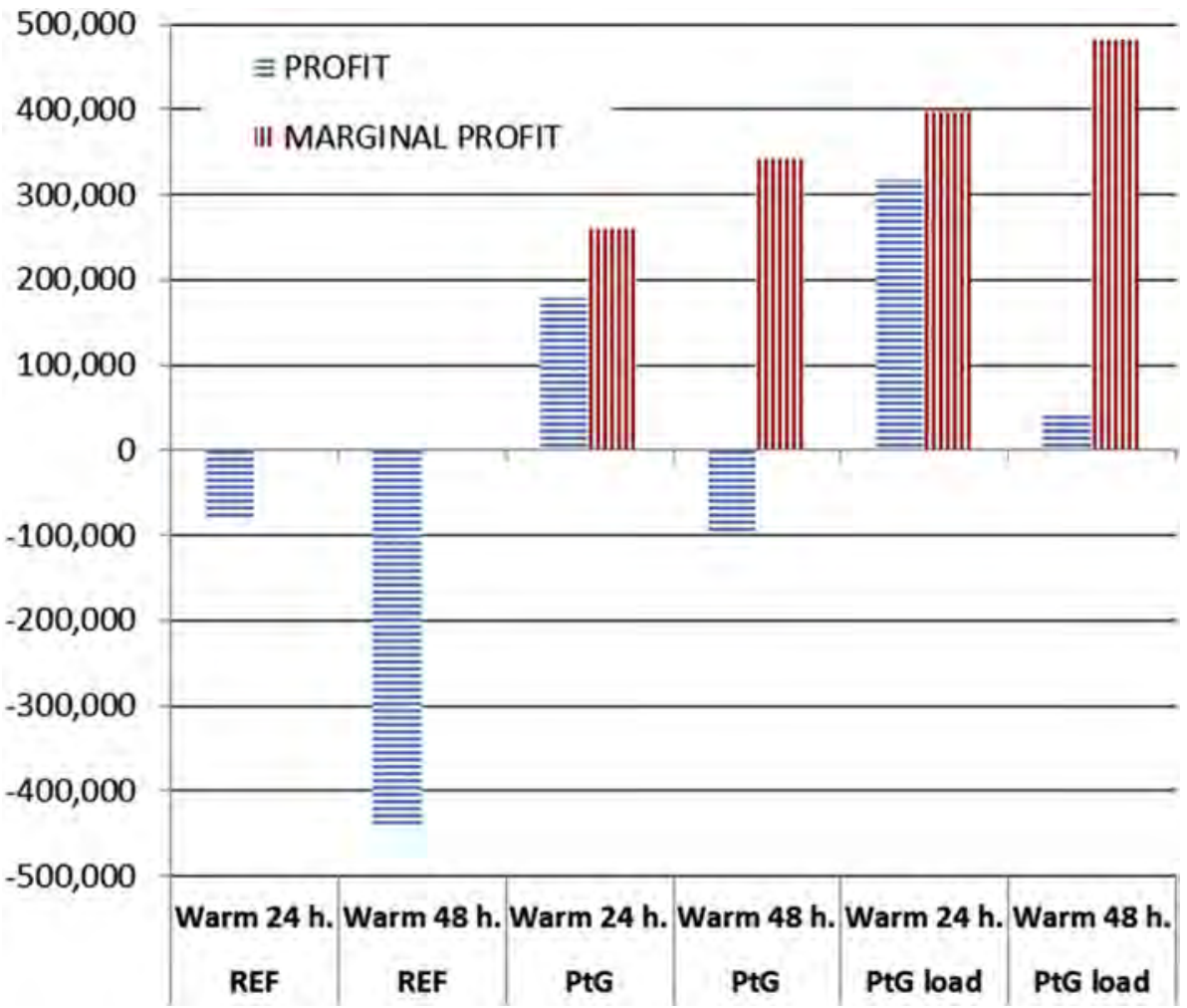

Fig. 5 - Comparison of profit and marginal profit under Scenario 2 assumptions for shutdown operation vs. continuous operation at MCL (PtG) vs. continuous operation at MCL (PtG) with temporary Full Load. 
Table 5 - Conventional shutdown operation vs. continuous operation at MCL (PtG) vs. continuous operation at MCL (PtG) with temporary Full Load, under Scenario 3 assumptions. Bold represents the key variables of the system.

\begin{tabular}{|c|c|c|c|c|c|c|}
\hline Case & $\begin{array}{l}\text { Conventional } \\
\text { shutdown }\end{array}$ & $\begin{array}{c}\text { MCL } \\
\text { with PtG }\end{array}$ & $\begin{array}{l}\text { MCL with PtG and } \\
\text { temporary FL }\end{array}$ & $\begin{array}{l}\text { Conventional } \\
\text { shutdown }\end{array}$ & $\begin{array}{c}\text { MCL } \\
\text { with PtG }\end{array}$ & $\begin{array}{l}\text { MCL with PtG and } \\
\text { temporary FL }\end{array}$ \\
\hline Start-up & Cold & $\mathrm{n} / \mathrm{a}$ & $\mathrm{n} / \mathrm{a}$ & Cold & $\mathrm{n} / \mathrm{a}$ & $\mathrm{n} / \mathrm{a}$ \\
\hline Shutdown duration [h] & 72 & 72 & 72 & 96 & 96 & 96 \\
\hline Temporary Full Load duration [h] & $\mathrm{n} / \mathrm{a}$ & $\mathrm{n} / \mathrm{a}$ & 24 & $\mathrm{n} / \mathrm{a}$ & $\mathrm{n} / \mathrm{a}$ & 24 \\
\hline Time frame $[\mathrm{h}]$ & 120 & 120 & 120 & 120 & 120 & 210 \\
\hline \multicolumn{7}{|l|}{ Technical data } \\
\hline Input coal $\left[\mathrm{MWh}_{\mathrm{th}}\right]$ & $35,198.55$ & $95,732.66$ & $111,259.72$ & 1939.28 & $80,231.25$ & $95,758.31$ \\
\hline Electricity produced (total) $\left[\mathrm{MWh}_{\mathrm{e}}\right]$ & $13,822.50$ & $32,595.00$ & $40,685.00$ & 736.25 & $24,555.00$ & $32,595.00$ \\
\hline $\begin{array}{l}\text { Electricity production increment with } \\
\text { respect to conventional shutdown }\left[\mathrm{MWh}_{\mathrm{e}}\right]\end{array}$ & $\mathrm{n} / \mathrm{a}$ & $18,772.50$ & $26,862.50$ & $\mathrm{n} / \mathrm{a}$ & $23,818.75$ & $31,858.75$ \\
\hline Electricity directed to PtG $\left[\mathrm{MWh}_{\mathrm{e}}\right]$ & $\mathrm{n} / \mathrm{a}$ & 3600 & 2400 & $\mathrm{n} / \mathrm{a}$ & 4800 & 3600 \\
\hline Stored energy $\left(\mathrm{H}_{2}\right)$ [MWh] & $\mathrm{n} / \mathrm{a}$ & 2700 & 1800 & $\mathrm{n} / \mathrm{a}$ & 3600 & 2700 \\
\hline $\mathrm{CO}_{2}$ emissions $[\mathrm{t}]$ & 11,616 & 31,592 & 36,716 & 640 & 26,476 & 31,600 \\
\hline \multicolumn{7}{|l|}{ Economic data } \\
\hline Costs $[€]$ & 944,059 & $2,101,932$ & $2,280,242$ & 573,066 & $1,923,877$ & $2,102,188$ \\
\hline Start-up cost $[€]$ & 140,000 & $\mathrm{n} / \mathrm{a}$ & $\mathrm{n} / \mathrm{a}$ & 140,000 & $\mathrm{n} / \mathrm{a}$ & $\mathrm{n} / \mathrm{a}$ \\
\hline Total costs $[€]$ & $1,084,059$ & $2,101,932$ & $2,280,242$ & 713,066 & $1,923,877$ & $2,102,188$ \\
\hline $\begin{array}{l}\text { Cost increment with respect to conventional } \\
\text { shutdown }[€]\end{array}$ & $\mathrm{n} / \mathrm{a}$ & $1,017,873$ & $1,196,183$ & $\mathrm{n} / \mathrm{a}$ & $1,210,811$ & $1,389,122$ \\
\hline Incomes electricity [€] & 829,350 & $1,955,700$ & $2,441,100$ & 44,175 & $1,473,300$ & $1,955,700$ \\
\hline Incomes $\mathrm{H}_{2}[€]$ & $\mathrm{n} / \mathrm{a}$ & 81,000 & 54,000 & $\mathrm{n} / \mathrm{a}$ & 108,000 & 81,000 \\
\hline Total Incomes $[€]$ & 829,350 & $2,036,700$ & $2,495,100$ & 44,175 & $1,581,300$ & $2,036,700$ \\
\hline Profit $[€]$ & $-254,709$ & $-65,232$ & 214,858 & $-668,891$ & $-342,577$ & $-65,488$ \\
\hline Differential profit $[€ / 24 \mathrm{~h}]$ & $\mathrm{n} / \mathrm{a}$ & 189,477 & 469,567 & $\mathrm{n} / \mathrm{a}$ & 326,314 & 603,403 \\
\hline Differential hourly profit $[€ / h]$ & $\mathrm{n} / \mathrm{a}$ & 1579 & 3913 & $\mathrm{n} / \mathrm{a}$ & 2719 & 5028 \\
\hline Specific cost of electricity $\left[€ / \mathrm{MWh}_{\mathrm{e}}\right]$ & 68.30 & 64.49 & 56.05 & 778.36 & 78.35 & 64.49 \\
\hline $\begin{array}{l}\text { Specific cost of additional electricity } \\
\text { [€/MWh] }\end{array}$ & $\mathrm{n} / \mathrm{a}$ & 54.22 & 44.53 & $\mathrm{n} / \mathrm{a}$ & 50.83 & 43.60 \\
\hline
\end{tabular}

up cost only influence in the reference case. The influence in the total cost is larger than this $10 \%$ and increases up to $15 \%$. In any case, the net profit remains in similar values to the base case. In the rest of the cases, similar trends are observed.

The final economic profit depends more on each specific case shorter or larger stops and/or days to consider in calculations ( $24 \mathrm{~h}$ or $120 \mathrm{~h}$ ) than in variation of the main economic assumptions. The most attractive scenario would be a case with low coal costs as the profit, in the cases which make use of PtG, is larger than in reference case. Since the coal PP does not stop, continue in operation and coal is used in these hours.
For sake of clarity, data from the sensitivity analysis are illustrated in Fig. 6 for those cases with a reference frame time of $24 \mathrm{~h}$ (hot start-ups) and those cases with a reference frame time of $120 \mathrm{~h}$ (cold start-ups). The three variables that have been modified are the investment cost of the PtG facility, the cost of the fuel and the cost of shutting down the power plant. Their variation is represented in $\mathrm{X}$-axis while the variation of profit under the different studied scenarios is represented in the Y-axis. The slope of the represented lines indicates the significance of each economic parameter. At the light of Fig. 5 , the cost of fuel appears to be the most relevant economic parameter under all of the studied scenarios.

Table 6 - Sensitivity analysis under the Scenario 1 and 3 assumptions. Economical results with variations of the PtG CAPEX, coal cost and shut-down and start-up costs. Bold represents the key variables of the system.

\begin{tabular}{|c|c|c|c|c|c|c|c|}
\hline & \multicolumn{4}{|c|}{ REFERENCE $24 \mathrm{~h}$} & \multicolumn{3}{|c|}{ REFERENCE $120 \mathrm{~h}$} \\
\hline & $\mathrm{REF}$ & REF & PtG & PtG & REF & PtG & PtG load \\
\hline & Hot $6 \mathrm{~h}$. & Hot $12 \mathrm{~h}$. & Hot $6 \mathrm{~h}$. & Hot $12 \mathrm{~h}$. & Cold 72 h. & Cold 72 h. & Cold 72 h. \\
\hline PROFIT. Base case & $-48,786$ & $-138,758$ & 76,075 & 6738 & $-254,709$ & $-65,232$ & 214,858 \\
\hline$+20 \%$ cost PtG & $-48,786$ & $-138,758$ & 73,688 & 4351 & $-254,709$ & $-77,166$ & 202,924 \\
\hline$-20 \%$ cost PtG & $-48,786$ & $-138,758$ & 78,462 & 9125 & $-254,709$ & $-53,297$ & 226,792 \\
\hline$+10 \%$ cost coal & $-66,431$ & $-149,260$ & 51,999 & $-13,462$ & $-289,908$ & $-160,964$ & 103,598 \\
\hline$-10 \%$ cost coal & $-31,141$ & $-128,255$ & 100,151 & 26,939 & $-219,510$ & 30,501 & 326,118 \\
\hline$+10 \%$ cost stops & $-56,286$ & $-146,258$ & 76,075 & 6738 & $-256,109$ & $-65,232$ & 214,858 \\
\hline$-10 \%$ cost stops & $-41,286$ & $-131,258$ & 76,075 & 6738 & $-253,309$ & $-65,232$ & 214,858 \\
\hline
\end{tabular}



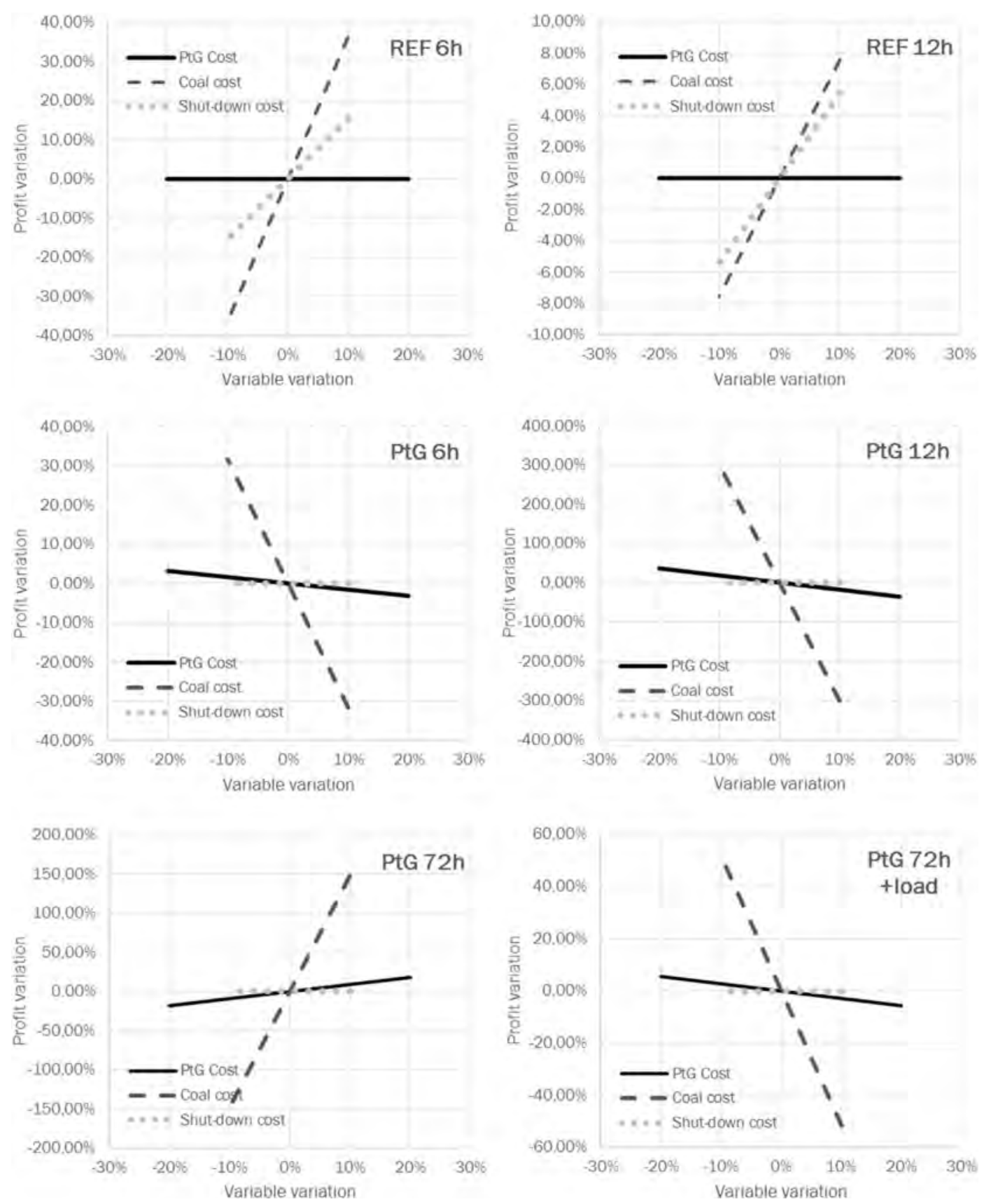

Fig. 6 - Sensitivity analysis of most significant economic variables.

\section{Conclusions}

The increase of the renewable share in the energy generation mix affects the operational predictability and flexibility of the grid operator. This situation compels coal-fired power plants to improve their operational flexibility and face frequent shutdowns, increasing the generation cost.

An option to deal with this problem is to integrate energy storage systems in power plants to instantaneously respond to load changes, virtually reduce their minimum complaint load and avoid shutdowns caused by an increase of renewable share in the electrical grid. In this work, we have studied their coupling with Power to Hydrogen energy storage for this purpose. Instead of shutting down the power plant, part of the power produced is diverted to an electrolyser that virtually allows to the power below the minimum complaint load and maintain the power plant in operation.

The paper presents the comparison of (i) conventional shutdowns, (ii) continuous operation at minimum complaint load thanks to the utilisation of Power to Gas, and (iii) operation at MCL through PtG with a temporary increment to full load during the outage, required by the grid operator. Three scenarios are established for the analysis, corresponding to hot-, warm- and cold start-ups. The assessments are performed within the time frames of $24 \mathrm{~h}, 72 \mathrm{~h}$ and $120 \mathrm{~h}$ duration, respectively. 
In Scenario 1, the utilisation of PtG to virtually reduce the MCL allows diminishing the specific cost of producing electricity a $21.8 \%-34.7 \%$, compared to the cost related to shutdowns of 6-12 h duration. Thus, positive profit is obtained instead of economic losses. The main contribution to this profitable situation is saving the costs of the shutdown rather than the incomes from the sale of the hydrogen.

In Scenario 2, the utilisation of Power to Gas reduces the specific cost of producing electricity to $54.2-68.7 € / \mathrm{MWh}_{\mathrm{e}}$, for shutdowns of 24-48 h that are framed in a total period of $72 \mathrm{~h}$ duration. Hence, PtG utilisation is not enough to reduce the cost of generating electricity below the selling price (60€/ $\mathrm{MWh}_{\mathrm{e}}$ ) at long shutdowns. To convert the situation into a profitable scenario, it must be assumed that the grid operator requires a temporary load increment to $100 \%$ while the power plant is dispatching electricity at MCL. If the duration of this requirement is $12 \mathrm{~h}$ (out of the $72 \mathrm{~h}$ of the time frame), the specific cost of electricity does fall below the selling price, to the range of $49.9-60.1 € / \mathrm{MWh}_{\mathrm{e}}$.

In Scenario 3, profitable scenarios are even more restricted. Costs of electricity generation below the selling price are only achieve for relatively short periods of outage and mandatory load increments from the grid operator. Therefore, avoiding losses as much as possible is the main objective in this Scenario.

Sensitivity analysis shows that the most relevant variables in economy do not essentially change the conclusions drawn. Coal price is the most important variable in the economic calculations. A reduction in coal price increases the profit of the proposed concept as maintain in operation the coal PP at low load and avoid the shut-down costs.

In summary, it has been shown that Power to Gas may convert scenarios with economic losses into profitable situations through the avoidance of shutdown costs. Besides, even when scenarios cannot be reverted to profitable situations, the economic losses are highly reduced. Also, it is worth to mention that in some cases, even if the cost of producing electricity is not reduced below the selling price, the incomes from the sale of the hydrogen may cover the difference and help achieving profitable scenarios.

\section{Acknowledgments}

The work described in this paper is supported by the $\mathrm{R}+\mathrm{D}$ Spanish National Program from Ministerio de Economía y Competitividad, MINECO (Spanish Ministry of Economy and Competitiveness) and the European Regional Development Funds (European Commission), under project ENE2016-76850R.

This work has also been supported by the Government of Aragon and co-financed by FEDER 2014-2020 "Construyendo Europa desde Aragón” (Research Group DGA T46_17R, and project LMP134_18).

\section{Nomenclature}

FFPP Fossil fuel power plants

FSNL Full speed no load

FL Full load
MCL Minimum complaint load

NSNL No speed no load

O\&M Operation and Maintenance

PtG Power to Gas

REF Reference case

R E F E R E N C E S

[1] Mikulčić H, Ridjan Skov I, Dominković DF, Wan Alwi SR, Manan ZA, Tan R, Duić N, Hidayah Mohamad SN, Wang X. Flexible Carbon Capture and Utilization technologies in future energy systems and the utilization pathways of captured $\mathrm{CO}_{2}$. Renew Sustain Energy Rev 2019;114. https:// doi.org/10.1016/j.rser.2019.109338.

[2] United nations framework convention on climate change. Paris Agreement; 2015.

[3] European Commission. Directive (EU) 2018/2001 of the European Parliament and of the Council of 11 December 2018 on the promotion of the use of energy from renewable sources. 2018.

[4] IEA. Renewables 2017. Paris. 2017.

[5] Nadeem F, Hussain SMS, Tiwari PK, Goswami AK, Ustun TS. Comparative review of energy storage systems, their roles, and impacts on future power systems. IEEE Access 2019;7:4555-85. https://doi.org/10.1109/ ACCESS.2018.2888497.

[6] Martín M, Grossmann IE. Optimal integration of renewable based processes for fuels and power production: Spain case study. Appl Energy 2018;213:595-610. https://doi.org/10.1016/ j.apenergy.2017.10.121.

[7] Eser P, Singh A, Chokani N, Abhari RS. Effect of increased renewables generation on operation of thermal power plants. Appl Energy 2016;164:723-32. https://doi.org/10.1016/ j.apenergy.2015.12.017.

[8] Benato A, Bracco S, Stoppato A, Mirandola A. LTE: a procedure to predict power plants dynamic behaviour and components lifetime reduction during transient operation. Appl Energy 2016;162:880-91. https://doi.org/10.1016/ j.apenergy.2015.10.162.

[9] Mertens N, Alobaid F, Starkloff R, Epple B, Kim HG. Comparative investigation of drum-type and once-through heat recovery steam generator during start-up. Appl Energy 2015;144:250-60. https://doi.org/10.1016/j.apenergy.2015.01.065.

[10] Zhao Y, Fan P, Wang C, Liu M, Chong D, Yan J. Fatigue lifetime assessment on a high-pressure heater in supercritical coal-fired power plants during transient processes of operational flexibility regulation. Appl Therm Eng 2019;156:196-208. https://doi.org/10.1016/ j.applthermaleng.2019.04.066.

[11] Dong Y, Jiang X, Liang Z, Yuan J. Coal power flexibility, energy efficiency and pollutant emissions implications in China: a plant-level analysis based on case units. Resour Conserv Recycl 2018;134:184-95. https://doi.org/10.1016/ J.RESCONREC.2018.03.012.

[12] Lew D, Brinkman G, Kumar N, Lefton S, Jordan G, Venkataraman S. Finding flexibility. Cycling the conventional fleet. IEEE Power Energy Mag 2013:20-32. https://doi.org/10.1109/MPE.2013.2277988.

[13] de Groot M, Crijns-Graus W, Harmsen R. The effects of variable renewable electricity on energy efficiency and full load hours of fossil-fired power plants in the European Union. Energy 2017;138:575-89. https://doi.org/10.1016/ J.ENERGY.2017.07.085.

[14] Schill W-P, Zerrahn A. Long-run power storage requirements for high shares of renewables: results and sensitivities. 
Renew Sustain Energy Rev 2018;83:156-71. https://doi.org/ 10.1016/j.rser.2017.05.205.

[15] Brouwer AS, Van Den Broek M, Seebregts A, Faaij A. Operational flexibility and economics of power plants in future low-carbon power systems. Appl Energy 2015;156:107-28. https://doi.org/10.1016/ j.apenergy.2015.06.065.

[16] Hentschel J, Babić U, Spliethoff H. A parametric approach for the valuation of power plant flexibility options. Energy Rep 2016;2:40-7. https://doi.org/10.1016/j.egyr.2016.03.002.

[17] Romeo LM, Peña B, Bailera M, Lisbona P. Analysis of the influence of Power-to-Gas systems in cyclic performance of fossil fuel power plants. In: ECOS 2018 - proc. 31st int. Conf. Effic. Cost, optim. Simul. Environ. Impact energy syst.; 2018.

[18] Yin S, Zhang S, Andrews-Speed P, Li W. Economic and environmental effects of peak regulation using coal-fired power for the priority dispatch of wind power in China. J Clean Product 2017;162:361-70. https://doi.org/10.1016/ j.jclepro.2017.06.046.

[19] Garðarsdóttir S, Göransson L, Normann F, Johnsson F. Improving the flexibility of coal-fired power generators: impact on the composition of a cost-optimal electricity system. Appl Energy 2018;209:277-89. https://doi.org/ 10.1016/j.apenergy.2017.10.085.

[20] Forman C, Gootz M, Wolfersdorf C, Meyer B. Coupling power generation with syngas-based chemical synthesis. Appl Energy 2017;198:180-91. https://doi.org/10.1016/ j.apenergy.2017.04.053.

[21] Dincer I, Acar C. Smart energy solutions with hydrogen options. Int J Hydrogen Energy 2018;43:8579-99. https:// doi.org/10.1016/j.ijhydene.2018.03.120.

[22] Maggio G, Nicita A, Squadrito G. How the hydrogen production from RES could change energy and fuel markets: a review of recent literature. Int J Hydrogen Energy 2019;44:11371-84. https://doi.org/10.1016/ j.ijhydene.2019.03.121.

[23] Moriarty P, Honnery D. Prospects for hydrogen as a transport fuel. Int J Hydrogen Energy 2019;44:16029-37. https://doi.org/ 10.1016/j.ijhydene.2019.04.278.

[24] Vandewalle J, Bruninx K, D'haeseleer W. Effects of largescale power to gas conversion on the power, gas and carbon sectors and their interactions. Energy Convers Manag 2015;94:28-39. https://doi.org/10.1016/ j.enconman.2015.01.038.

[25] Bailera M, Lisbona P, Romeo LM, Espatolero S. Power to Gas projects review: lab, pilot and demo plants for storing renewable energy and $\mathrm{CO}_{2}$. Renew Sustain Energy Rev 2017;69. https://doi.org/10.1016/j.rser.2016.11.130.

[26] Bailera M, Kezibri N, Romeo LM, Espatolero S, Lisbona P, Bouallou C. Future applications of hydrogen production and CO2 utilization for energy storage: hybrid Power to GasOxycombustion power plants. Int J Hydrogen Energy 2017;42. https://doi.org/10.1016/j.ijhydene.2017.02.123.

[27] Bailera M, Lisbona P, Romeo LM. Avoidance of partial load operation at coal-fired power plants by storing nuclear power through power to gas. Int J Hydrogen Energy
2019;44:26063-75. https://doi.org/10.1016/

j.ijhydene.2019.08.033.

[28] Matute G, Yusta JM, Correas LC. Techno-economic modelling of water electrolysers in the range of several MW to provide grid services while generating hydrogen for different applications: a case study in Spain applied to mobility with FCEVs. Int J Hydrogen Energy 2019;44:17431-42. https:// doi.org/10.1016/j.ijhydene.2019.05.092.

[29] Gonzalez-Salazar MA, Kirsten T, Prchlik L. Review of the operational flexibility and emissions of gas- and coal-fired power plants in a future with growing renewables. Renew Sustain Energy Rev 2018;82:1497-513. https://doi.org/ 10.1016/j.rser.2017.05.278.

[30] Belošević S, Tomanović I, Crnomarković N, Milićević A, Tucaković D. Numerical study of pulverized coal-fired utility boiler over a wide range of operating conditions for in-furnace SO2/NOxreduction. Appl Therm Eng 2016;94:657-69. https://doi.org/10.1016/ j.applthermaleng.2015.10.162.

[31] Lenton R, Choudhuri G. Fuel and technology cost review final report. Australian Energy Market Operator; 2014.

[32] Proost J. State-of-the art CAPEX data for water electrolysers, and their impact on renewable hydrogen price settings. Int $J$ Hydrogen Energy 2019;44:4406-13. https://doi.org/10.1016/ j.ijhydene.2018.07.164.

[33] ACIL Tasman. Fuel resource, new entry and generation costs in the NEM - final Report. 2009.

[34] Nalbandian-Sugden $\mathrm{H}$. Operating ratio and cost of coal power generation. IEA Clean Coal Centre; 2016. https:// doi.org/978-92-9029-595-2.

[35] Kumar N, Besuner P, Lefton S, Agan D, Hilleman D. Power plant cycling costs. National Renewable Energy Laboratory; 2012.

[36] Parra D, Valverde L, Pino FJ, Patel MK. A review on the role, cost and value of hydrogen energy systems for deep decarbonisation. Renew Sustain Energy Rev 2019;101:279-94. https://doi.org/10.1016/j.rser.2018.11.010.

[37] BP Statistical Review of World Energy. BP. 2019. https://www. bp.com/content/dam/bp/business-sites/en/global/corporate/ pdfs/energy-economics/statistical-review/bp-stats-review2019-full-report.pdf.

[38] Eurostat., EU. Eurostat. Statistics explained. 2019.

[39] Strbac G, Shakoor A, Black M, Pudjianto D, Bopp T. Impact of wind generation on the operation and development of the UK electricity systems, Electr. Power Syst Res 2007;77:1214-27. https://doi.org/10.1016/j.epsr.2006.08.014.

[40] Guilera J, Ramon Morante J, Andreu T. Economic viability of SNG production from power and $\mathrm{CO}_{2}$. Energy Convers Manag 2018;162:218-24. https://doi.org/10.1016/ j.enconman.2018.02.037.

[41] Miao B, Chan SH. The economic feasibility study of a 100-MW Power-to-Gas plant. Int J Hydrogen Energy 2019;44:20978-86. https://doi.org/10.1016/j.ijhydene.2019.02.044.

[42] Parra D, Patel MK. Techno-economic implications of the electrolyser technology and size for power-to-gas systems. Int J Hydrogen Energy 2016;41:3748-61. https://doi.org/ 10.1016/j.ijhydene.2015.12.160. 